\title{
Vaginal washing fluid C-reactive protein levels in women with recurrent or treatment resistant vaginitis
}

\author{
Tekrarlayan veya tedaviye dirençli vajinit olgularında vajinal yıkama sıvısında C-reaktif \\ protein düzeyleri
}

Aytekin Tokmak, İrfan Özer, Selçuk Erkılınç, Ali İrfan Güzel, Mahmut Kuntay Kokanalı, Mustafa Uğur

\begin{abstract}
Objective: The aim of this study is to evaluate the C-reactive protein (CRP) levels in vaginal washing fluid (VWF) in women with a history of recurrent and/or treatment resistant vaginitis.

Methods: This prospective case control study was conducted in the gynecology clinic of the current hospital. A total of 64 women (33 with a history of recurrent and/ or treatment resistant vaginitis as study group and 31 healthy women as control group) were enrolled in the study. The recorded parameters were; age, presenting symptom, educational level, socioeconomic status, frequency of vaginal douching (VD), peripheral blood leukocyte count, CRP levels in VWF, vaginal culture, fresh vaginal smear and urinalysis.
\end{abstract}

Results: The study group had statistically significantly lower educational level and socioeconomic status than the control group $(p<0.05)$. The mean levels of peripheral blood leukocyte count and leukocyte count on the fresh vaginal smear, leukocyturia and VWF CRP levels were statistically significantly higher in the study group $(p<0.05)$. In patients who had $\geq 3$ times a week VD had also statistically significantly higher VWF CRP levels $(p=0.012)$.

Conclusion: According to this study, recurrent and/or treatment resistant vaginitis is more common in women who have lower socioeconomic status/educational level and who perform more frequently VD, and VWF CRP levels may be a good marker for the diagnosis of disease. $J$ Clin Exp Invest 2015; 6 (1): 5-9

Key words: C-reactive protein, recurrent vaginitis, treatment resistant vaginitis, vaginal washing fluid

\section{ÖZET}

Amaç: Bu çalışmanın amacı tekrarlayan ve/veya tedaviye dirençli vajinit öyküsü olan olgularda vajinal yıkama sıvısı C-reaktif protein (CRP) düzeylerinin değerlendirilmesidir.

Yöntemler: Bu prospektif vaka kontrollü çalışma hastanemizin jinekoloji kliniğinde yapılmıştır. Toplam 64 kadın (33 tekrarlayan ve/veya tedaviye dirençli vajinit öyküsü olan kadın çalışma grubu ve 31 sağlıklı kadın kontrol grubu) çalışmaya dâhil edilmiştir. Kaydedilen parametreler; yaş, başvuru şikâyeti, eğitim düzeyi, sosyoekonomik durum, vajinal duş (VD) sıklığı, periferik kan lökosit sayısı, vajinal sıvı CRP düzeyi, vajinal kültür, taze vajinal yayma ve idrar tetkikidir.

Bulgular: Çalışma grubu istatistiksel olarak anlamlı düzeyde daha düşük eğitim düzeyi ve sosyoekonomik duruma sahipti $(p<0,05)$. Periferik kanda ve taze vajinal sürüntüdeki ortalama lökosit sayısı, lökositüri ve vajinal yıkama sıvısı CRP düzeyleri çalışma grubunda istatistiksel anlamlı olarak daha yüksekti $(p<0,05)$. Ayrıca haftada $\geq 3$ kez VD yapanlarda vajinal yıkama sıvısı CRP düzeyleri istatistiksel olarak anlamlı yüksekti $(p=0,012)$.

Sonuç: Bu çalışmaya göre düşük sosyoekonomik durumu olan ve sık VD yapan kadınlarda tekrarlayan ve/veya tedaviye dirençli vajinit daha sık görülürken, bu hastalığın tanısında vajinal yıkama sıvısı CRP düzeyleri iyi bir belirteç olabilir

Anahtar kelimeler: C-reaktif protein, tekrarlayan vajinit, tedaviye dirençli vajinit, vajinal yıkama sıvısı 


\section{INTRODUCTION}

Vulvovaginal inflammation is identified as vulvovaginitis with symptoms such as leucorrhea, pruritus, soreness, dysuria and dyspareunia. The etiologic factors of vulvovaginitis are infectious, irritant, allergic, hormonal, iatrogenic, traumatic and dermatoses [1]. Bacterial vaginosis (BV), vulvovaginal candidiasis, and Trichomonas vaginalis are the most common causes of infectious vulvovaginitis and streptococcus, staphylococcus, and human immunodeficiency virus (HIV) are rare causes of vaginitis [2]. Bacterial vaginosis is the most common among these vaginal disorders. Vaginal douching (VD) is a common habit in women and is performed for personal hygiene or other aesthetic reasons. It is reported to be a frequent cause of BV and treatment resistant vaginitis especially in patients with lower socioeconomic status $[3,4]$. Tissue injury, infection and inflammation increase acute phase proteins. Creactive protein (CRP) is an acute phase protein [5]. Previous studies evaluated inflammatory cytokines in vaginal washing fluid $[6,7]$.

In current study, we aimed to determine the vaginal washing fluid's (VWF) CRP level in women with a history of recurrent and treatment-resistant vaginitis and association between demographic and clinical parameters.

\section{METHODS}

This prospective case-controlled study was conducted in the Zekai Tahir Burak Women's Health Education and Research Hospital, which is a referral tertiary hospital located in Ankara, Turkey. A total of 64 married women were recruited from gynecology outpatient clinic between May 2013 and July 2013. Thirty three of the patients who had a history of recurrent and treatment-resistant vaginitis constituted the study group, whereas 31 healthy women constituted the control group. Patients applied to our outpatient clinic for periodical routine examination or due to recurrent vaginal discharge. None of the patients in the study had clinically acute vaginitis during the pelvic examination. Each participant gave written informed consent by the time of sample collection and the study was approved by the hospital's local ethics committee.

The main parameters recorded for each woman were; age, parity, detailed medical history, educational level, socioeconomic status and frequency of VD. Participants were required to be at least three days past the end of the most recent menstruation, most recent unprotected penile-vaginal intercourse and most recent VD. They were also required to be at least three weeks past the most recent use of local or systemic anti-infective agents. Recurrent infection was defined as four or more occurrences of symptomatic vulvovaginitis in the past year whereas treatment resistant vulvovaginitis was defined as at least once occurrence consecutive symptomatic vulvovaginitis despite adequate treatment in the past year. The patients with acute and chronic infections, rheumatic and other inflammatory diseases, malignancy, tissue injury and necrosis, and cardiovascular diseases were excluded from the study. All of the patients were examined on dorsolithotomy position after a detailed sexual and medical history was obtained. During the vaginal exam a sterile speculum was introduced into the vagina to see the cervix, and fresh culture samples were taken from the cervix and vagina. After the fresh culture sample had been taken, $5 \mathrm{ml}$ sterile saline solution was injected into the vagina and aspirated from the posterior fornix with the same syringe. The procedure was completed with a bimanual pelvic examination. The VWF sample was centrifuged at $3000 \mathrm{rpm}$ for 10 minutes and was analyzed immediately. In this study we used an enzyme-linked immunosorbent assay to determine the levels of CRP in vaginal washing fluid. The patients with positive vaginal culture were excluded from the study.

\section{Statistical analysis}

Continuous variables were calculated by the mean and standard deviation. Independent sample t-test was performed to evaluate associations both continuous variables. Receiver operator characteristics curve (ROC) analysis was performed to find out the predictive role of vaginal washing fluid CRP levels in study group. The sample size was determined according to the results of the central limit theorem, which indicated that we needed at least 30 individuals in each subgroup [8]. Two-sided $p$ values were assumed statistically significant when $p<0.05$. Statistical analyses were performed using the SPSS software (ver. 17.0 for Windows; SPSS, Chicago, IL, USA).

\section{RESULTS}

The mean age of the patients was $31.8 \pm 7.4$. The median (minimum-maximum) parity of the patients was $2(0-9)$. The cases were divided into two groups according to having a history of recurrent and treatment resistant vaginitis (study group, $n=33$ ) or not (control group, $\mathrm{n}=31$ ). Table 1 showed the compari- 
son of these groups. The mean age and parity of the groups were similar $(p>0.05)$. The initial symptoms were also showed no difference between the groups. The white blood cell levels in blood and urine was statistically significantly higher in study group $(p<0.05)$. The mean vaginal washing fluid CRP levels were also significantly higher in the study group $(p=0.023)$.

Table 1. Comparison the demographic and clinical parameters of the groups

\begin{tabular}{lccc}
\hline & $\begin{array}{c}\text { Study group } \\
(\mathbf{n}=\mathbf{3 3})\end{array}$ & $\begin{array}{c}\text { Control group } \\
(\mathbf{n}=\mathbf{3 1})\end{array}$ & P value \\
\hline Age (years) & $31.0 \pm 7.5$ & $32.8 \pm 7.4$ & 0.349 \\
Parity & & & \\
$\quad \leq 2$ & 12 & 9 & 0.023 \\
$\quad>2$ & 21 & 22 & \\
Educational level & & & \\
$\quad$ Primary school & 15 & 8 & 0.041 \\
$\quad$ Secondary school and more & 18 & 23 & \\
Socioeconomic status (TL/month) & & & \\
$\quad<500$ & 3 & 2 & $<0.001$ \\
$\quad 500-1000$ & 21 & 10 & \\
$\quad>1000$ & 9 & 19 & 0.021 \\
White blood cell & $7.7 \pm 1.9$ & $5.1 \pm 2.0$ & 0.008 \\
Leukocyturia & $6.8 \pm 11.1$ & $2.5 \pm 4.8$ & 0.008 \\
Micro CRP & $0.22 \pm 0.29$ & $0.10 \pm 0.07$ & 0.023 \\
Fresh leukocyte & $7.6 \pm 8.0$ & $2.9 \pm 3.3$ & 0004 \\
\hline
\end{tabular}

The subsequent analysis were performed to evaluate the vaginal washing fluid CRP levels in patients who had VD or not and having lower socioeconomic status and educational level or not (Table 2). Patients who had more than three VD had statistically higher VWF CRP levels (0.012). Patients with lower socioeconomic status and educational level also had higher VWF CRP levels $(p<0.05)$.

ROC curve analysis demonstrated that VWF CRP levels may be a discriminative factor in recurrent and treatment resistant vaginitis with an area under the curve (AUC) of 0.65 (Figure 1). When the cut-off point for the CRP level was set to 0.125 , the sensitivity and specificity levels were found to be $72.7 \%$ and $74.2 \%$, respectively.

Table 2. Micro CRP levels according to the vaginal douching practice, socioeconomic status, and educational level

\begin{tabular}{lcc}
\hline Variables & Micro CRP & P value \\
\hline $\begin{array}{l}\text { Vaginal douching } \\
>3\end{array}$ & $0.29 \pm 0.33$ & 0.012 \\
$\quad \leq 2$ & $0.12 \pm 0.17$ & \\
Educational level & & \\
$\quad$ Primary school & $0.22 \pm 0.29$ & 0.04 \\
$\quad$ Secondary school and more & $0.12 \pm 0.1$ & \\
Socioeconomic status & & \\
$\quad \leq 1000$ TL & $0.26 \pm 0.27$ & \\
$>1000$ TL & $0.08 \pm 0.05$ & 0.001 \\
\hline
\end{tabular}

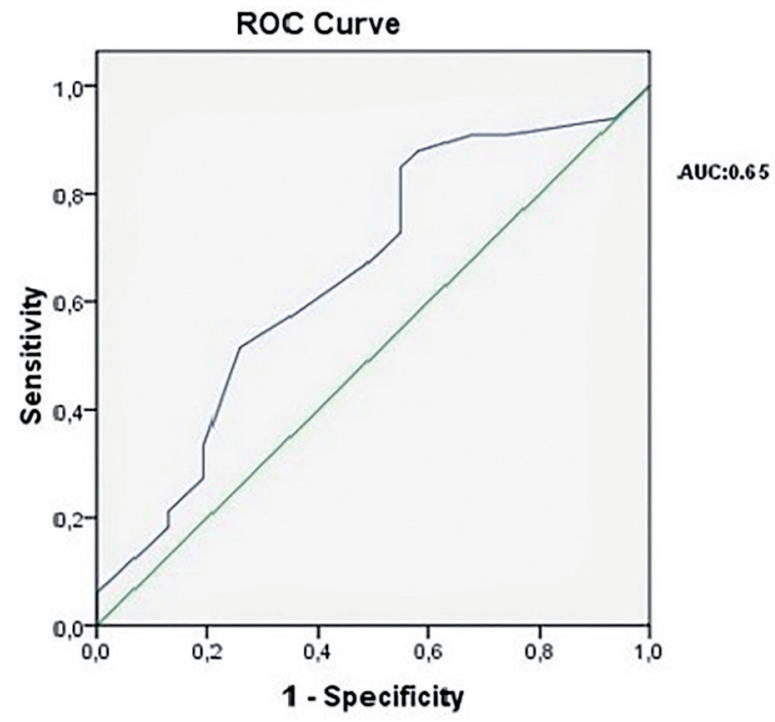

Figure 1. ROC curve analysis for micro $\mathrm{CRP}$ in prediction of recurrent/treatment resistant vaginitis

\section{DISCUSSION}

The main finding of the current study is that VWF CRP level is higher in patients with a history of recurrent and treatment resistant vulvovaginitis. It suggests that these patients may be inclined to give local immunological reactions. The risk factors of this condition are VD and lower socioeconomic status and educational level. 
Vulvovaginitis is a general term referring to many types of vaginal infection such as Gardnerella, Trichomonas or Candida species. The well-defined risk factors are wiping the anus posterior to anterior, tight-fitting, synthetic underwear use, douching, diabetes, immune suppression, HIV infection, multiple sexual partner, increased intercourse frequency, oral contraceptive and antibiotic use.

Recurrent infection is defined as four or more occurrences of symptomatic vulvovaginitis in a year, especially for candidiasis. Recurrence is usually caused by re-infection with the same organism from a vaginal reservoir. For women with such repeated infection, vaginal cultures should be obtained to search for treatment-resistant species, such as Candida glabrata.

Vaginal douching with water, soap, or chemical products is a common practice among women worldwide, especially those of lower socioeconomic status. The main causes of vaginal douching are genital hygiene and religious beliefs. Several studies have shown that VD disturbs the normal vaginal flora and increases the risk of vulvovaginitis $[9,10]$. Guzel et al [3] reported that vaginal douching is a common practice among women, especially those of lower educational and socioeconomic status. The frequency of VD was found to be the most important risk factors for these adverse effects including treatment resistant vulvovaginitis and pelvic inflammatory disease. The literature search showed that VD is associated with different etiologic agents including candidiasis, trichomoniasis or BV [10-12].

Klebanoff et al [13] found that the symptoms of vaginitis were vaginal discharge, odor, and wetness. Eckert et al [14] reported that vaginitis, especially candidiasis, mostly presents as vaginal itching and burning. Recurrent vulvovaginal candidiasis is a common cause of vaginal discharge, affecting over $50 \%$ of all women at least once in their life. In $5-10 \%$ of these women, this infection is recurring [15].

Trichomonas vaginalis is sexually transmitted disease that can be associated with cervicitis and urethritis beside vaginitis. Recurrence and treatment resistance is common in women infected with Trichomonas vaginalis [16].

$\mathrm{BV}$ is one of the most common causes of vaginal discharge in reproductive age women. A polimicrobial etiology probably is responsible. However, Schwebke et al [17] suggested that BV is initiated by sexually transmission of Gardnerella vaginalis. $\mathrm{BV}$ is associated with significant clinical conse- quences. There is an increased risk of HIV acquisition, preterm delivery and pelvic inflammatory disease in women with this infection [18-20]. A recent meta-analysis demonstrated that oral contraceptive use reduces the development of BV [21].

CRP is an acute phase protein which rises in response to inflammation. Its physiologic role is to activate the complement system, and to facilitate phagocytosis. The increase of the CRP occurs as a result of a rise in the concentration of interleukin 6 , which is produced by macrophages as well as adipocytes in response to a wide range of acute and chronic inflammatory conditions [5]. These inflammatory conditions cause release of interleukin 6 and other cytokines that trigger the synthesis of CRP and fibrinogen by the liver. CRP plays an important role in innate immunity as an early defense system against infections, and it is used mainly as a marker of inflammation [22].

Recent studies have focused on determining the importance of vaginal-associated immunity. The published literature search suggests that recurrent candidiasis is associated with a localized vaginal allergic response [23]. And it was also shown that patients with recurrent candidiasis had impairment in candida specific cellular immunity and over active neutrophil response $[24,25]$. Weissenbacher et al [26] found that some cytokines related to allergic response to the candida species was statistically significantly higher in vaginal fluid of women with recurrent vulvovaginal candidiasis. Lev-Sagie et al [27] reported that hyaluronan, a complex carbohydrate related to immune system, concentrations in vaginal lavage fluid were elevated significantly in women with a current acute recurrent vulvovaginal candidiasis. These patients also may have a polymorphism in the genes coding for antimicrobial proteins and anti-inflammatory cytokines such as mannose binding lectin and interleukin 4 [28,29]. Although the pathophysiology of recurrent vulvovaginitis to be continued to investigate, the main reason is still not explained.

To the best of our knowledge, this is the first study evaluating VWF CRP level in women with a history of recurrent or treatment resistant vulvovaginitis. The findings of this study are somewhat limited by certain aspects of the study design. Our sample size was also limited, and the findings must be verified in larger populations. And, although VWF CRP levels were statistically significantly higher in the study group, all results were in normal reference range in both groups. 
In conclusion, according to this study we found that patients with lower socioeconomic status and educational level had more treatment resistant and recurrent vaginitis. VD frequency was also higher in this group and we think that related to these conditions VWF CRP levels were higher in these patients. Therefore this marker may be used to determine the patients who will develop recurrence and treatment resistant vulvovaginitis in advance. Larger and further studies are required to evaluate the predictive value of VWF CRP levels in recurrent and treatment resistant vulvovaginitis.

\section{Conflict of interest}

We declare that we have no conflict of interest.

\section{REFERENCES}

1. Ramírez SA, Pereiro MJ, Toribio J. Recurrent vulvovaginitis: diagnostic assessment and therapeutic management. Actas Dermo-Sifiliográficas 2008;99:190-198.

2. Sivaranjini R, Jaisankar T, Thappa D.M, et al. Spectrum of vaginal discharge in a tertiary care setting. Trop Parasitol 2013;3:135-139.

3. Guzel Al, Kuyumcuoglu U, Celik Y. Vaginal douching practice and related symptoms in a rural area of Turkey. Arch Gynecol Obstet 2011;284:1153-1156.

4. Shaaban OM, Youssef AE, Khodry MM, et al. Vaginal douching by women with vulvovaginitis and relation to reproductive health hazards. BMC Women's Health 2013;13-23:1-6.

5. Pepys MB, Hirschfield GM. C-reactive protein: a critical update. J Clin Invest 2003;111:1805-1812.

6. Ni CY, Jia WX, Yi WM, et al. Practicability of using vaginal fluid markers in detecting premature rupture of membranes. Ann Clin Biochem. 2003;40:542-545.

7. Torbé A, Czajka R. Are vaginal fluid procalcitonin levels useful for the prediction of subclinial infection in patients with preterm premature rupture of membranes? J Obstet Gynaecol Res 2005;31:464-470.

8. Celik Y. Biostatistics, principles of research. $2^{\text {nd }}$ edition. Diyarbakir: Dicle University Press. 2007.

9. Pavlova S.I, Tao L. In vitro inhibition of commercial douche products against vaginal microflora. Infect Dis Obstet Gynecol 2000;8:99-104.

10. Brotman RM, Klebanoff MA, Nansel TR, et al. A longitudinal study of vaginal douching and bacterial vaginosis-a marginal structural modeling analysis. Am J Epidemiol 2008;168:188-196.

11. Sutton M, Sternberg M, Koumans EH, et al. The prevalence of Trichomonas vaginalis infection among reproductive-age women in the United States, 2001-2004. Clin Infect Dis 2007;45:1319-1326.

12. Heng L.S, Yatsuya H, Morita S, et al. Vaginal douching in Cambodian women: its prevalence and association with vaginal candidiasis. J Epidemiol 2009;20:70-76.

13. Klebanoff MA, Nansel TR, Brotman RM, et al. Personal hygienic behaviours and bacterial vaginosis. Sex Transm Dis 2010;37:94-99.
14. Eckert LO, Hawes SE, Stevens CE, et al. Vulvovaginal candidiasis: clinical manifestations, risk factors, management algorithm. Obstet Gynecol 1998;92:757-765.

15. Corsello S, Spinillo A, Osnengo G, et al. An epidemiological survey of vulvovaginal candidiasis in Italy. Eur $\mathrm{J}$ Obstet Gynecol Reprod Biol 2003;110:66-72.

16. Seña AC, Bachmann LH, Hobbs MM. Persistent and recurrent Trichomonas vaginalis infections: epidemiology, treatment and management considerations. Expert Rev Anti Infect Ther 2014;12:673-685.

17. Schwebke JR, Muzny CA, Josey WE. Role of Gardnerella vaginalis in the Pathogenesis of Bacterial Vaginosis: A Conceptual Model. J Infect Dis 2014; [Epub ahead of print].

18. Hillier S.L, Nugent R.P, Eschenbach D.A, et al. Association between bacterial vaginosis and preterm delivery of a low-birthweight infant. The Vaginal Infections and Prematurity Study Group. N Engl J Med 1995;333:17371742.

19. Martin HL, Richardson BA, Nyange PM, et al. Vaginal lactobacilli, microbial flora, and risk of human immunodeficiency virus type 1 and sexually transmitted disease acquisition. J Infect Dis 1999;180:1863-1868.

20. Wiesenfeld HC, Hillier SL, Krohn MA, et al. Bacterial vaginosis is a strong predictor of Neisseria gonorrhoeae and Chlamydia trachomatis infection. Clin Infect Dis 2003;36:663-668.

21. Vodstrcil LA, Hocking JS, Law M, et al. Hormonal contraception is associated with a reduced risk of bacterial vaginosis: a systematic review and meta-analysis. PLoS One 2013;8:1-32.

22. Thompson D, Pepys MB, Wood SP. The physiological structure of human C-reactive protein and its complex with phosphocholine. Structure 1999;7:169-177.

23. Witkin S.S, Jeremias J, Ledger W.J. Recurrent vaginitis as a result of sexual transmission of IgE antibodies. Am J Obstet Gynecol 1988;159:32-36.

24. Nawrot U, Grzybek H.K, Zielska U, et al. The study of cell-mediated immune response in recurrent vulvovaginal candidiasis. FEMS Immunol Microbiol 2000;29:89-94.

25. Fidel PL. History and new insights into host defense against vaginal candidiasis. Trends Microbiol 2004;12:220-227.

26. Weissenbacher TM, Witkin SS, Gingelmaier A, et al. Relationship between recurrent vulvovaginal candidosis and immune mediators in vaginal fluid. Eur J Obstet Gynecol Reprod Biol 2009;144:59-63.

27. Lev SA, Nyirjesy $P$, Tarangelo $N$, et al. Hyaluronan in vaginal secretions: association with recurrent vulvovaginal candidiasis. Am J Obstet Gynecol 2009;201:206.e15.

28. Babula O, Lazdane G, Kroica J, et al. Relation between recurrent vulvovaginal candidiasis, vaginal concentrations of mannose-binding lectin and a mannose-binding lectin gene polymorphism in Latvian women. Clin Infect Dis 2003;37:733-737.

29. Babula O, Lazdāne G, Kroica J, et al. Frequency of interleukin-4 (IL-4) -589 gene polymorphism and vaginal concentrations of IL-4, nitric oxide and mannose-binding lectin in women with recurrent vulvovaginal candidiasis. Clin Infect Dis 2005;40:1258-1262. 